To Cite: Hanoğlu Oral H, Gökkuş A, 2021. Evaluation of Total Roughage Production and its Sufficiency for Livestock in Turkey. Journal of the Institute of Science and Technology, 11(3): 2423-2433.

\title{
Evaluation of Total Roughage Production and its Sufficiency for Livestock in Turkey
}

\section{Hülya HANOĞLU ORAL ${ }^{1 *}$ Ahmet GÖKKUŞ ${ }^{2}$}

\begin{abstract}
In this study, total roughage production and its sufficiency for farm animals in Turkey was evaluated. Because of insufficient production, feed prices are relatively high and fluctuating in Turkey. It was estimated that, the total 40363210 tonnes of roughages production in Turkey was supplied by meadows and pastures (13 164210 tonnes), shrublands (11 267000 tonnes) and forage crops production (15932000 tonnes). In addition, total straw and stubble production was estimated as 31074800 tonnes for animal feed, indicating that half of the total roughages production in Turkey came from straw and stubble production. In Turkey, the large and small ruminant stock is composed of a total of 17066900 animal units and in order to meet only the maintenance requirements of these animals via roughage, 77867731 tons of roughage is needed in 2019. Considering the daily dry roughage requirement as $12.5 \mathrm{~kg}$ (approximately 2.5 percent of total $500 \mathrm{~kg}$ live weight), deficiency of daily feed amount was estimated as $1.032 \mathrm{~kg}$ per animal unit and a total of 6429720 tonnes in 2019 in Turkey. If shrublands, straw and stubble production is neglected or removed from the calculation, then total deficiency reaches at 48771521 tonnes year-1 (62.63\% of the total feed requirement). For a rational animal feeding, not only the maintenance requirements of the animals but also, in addition to their maintenance requirements, at least $5-7 \mathrm{~kg}$ of milk production requires meeting from quality roughages. In this case, it is clear that the need for roughage will increase more. In Turkey, suffering from roughage shortage that adversely affecting production obtained from small and large ruminants, high quality forage production should be, at least, doubled by using every possible resource including natural rangelands, fallows, and cultivated lands effectively without compromising soil conservation and feed costs principles.
\end{abstract}

Keywords: Forage crops, rangelands, straw and stubble, shrublands, roughage need

${ }^{1}$ Hülya HANOĞLU ORAL (Orcid ID: 0000-0003-3626-9637), Muş Alparslan Üniversitesi, Uygulamalı Bilimler Fakültesi, Hayvansal Üretim ve Teknolojileri Bölümü, Muş, Türkiye

${ }^{2}$ Ahmet GÖKKUŞ (Orcid ID: 0000-0002-8549-8498), Çanakkale Onsekiz Mart Üniversitesi, Ziraat Fakültesi, Tarla Bitkileri Bölümü, Çanakkale, Türkiye

*Sorumlu Yazar/Corresponding Author: Hülya HANOĞLU ORAL, e-mail: h.hanoglu@alparslan.edu.tr 


\section{INTRODUCTION}

As a result of the increase in the agricultural support, important increases have been observed in the numbers of both small and large ruminants and culture and cross-bred animals in Turkey since 2010. While the total livestock was 10186300 animal units (AU) in 2010, it increased to 17066900 AU via increasing by $67.55 \%$ in 2019 . Moreover, the number of culture and cross-bred cattle has increased from 8905078 heads to 16114480 heads $(80.96 \%$ ) in this period as well (TÜIK, 2020b). In parallel to these increases, the need for roughage required to feed these animals increased as well, but a production increase has not been achieved at a desired level. For this reason, the quality roughage production of Turkey falls short of meeting even the maintenance requirements of the existing animal stock. However, for a rational animal feeding, not only the maintenance requirements of animals but also at least $5-7 \mathrm{~kg}$ of milk production should be met from quality roughages (Alçiçek et al., 2010; Alçiçek, 2012).

Roughages with high crude fiber content but low digestible organic matter and energy values are appropriate for animal nutrition physiology as well as decrease the use of more expensive concentrate feeds in animal nutrition. The use of roughages with lower costs compared to concentrate feeds increases the profitability in livestock enterprises (Alçiçek et al., 2010).

Quality roughage is obtained from two main sources, namely rangelands and forage crops cultivation. About half of the rangelands, which covered an area of 28.7 million hectares in 1960, have been lost during the period of 60 years and today they have decreased to 14.6 million hectares (Erdoğan, 1996; Anonymous, 2020b). Moreover, early and heavy grazing lasting for many years has led to decrease the yield potential of rangelands. At the same time, forage crops cultivation, another important source of quality roughage, has not developed sufficiently, either. While the share of forage crop areas within the cultivation areas ranges between 20-30\% in countries with developed livestock farming (Acar, 2017), this share is only $13.6 \%$ in Turkey (TÜIK, 2020a).

In the lead of the problems related to animal nutrition in Turkey come not only the insufficiency of roughage production but also the low quality of an important part of existing roughages. In fact, most of the total roughage used in animal feeding is composed of non-quality feeds with low nutritive value like straw, stubble and seed residues (Temel and Şahin, 2011). The use of straw commonly in order to meet the deficit of roughage leads to not only health and nutrition problems in animals but also reproduction and yield losses (Ak and Akbay, 2018). The nutrient needs of animals, which cannot only be met via roughages, are met via expensive concentrate or mixed, also edible, forages. In Turkey, especially beef cattle and dairy cattle raising are performed mainly based on concentrate feed. This preference or necessity both increases costs and foreign-source dependency and leads to the increase in metabolism diseases and digestive troubles in cattle. The problems of the ruminant raising in Turkey related to forage are not limited only to the insufficiency and the poor quality of roughage. In addition to this, one of the matters of complaint for animal breeders is the relatively high and fluctuating prices of forage. Such that, apart from alfalfa hay, even straw is sold at high prices and even imported from time to time.

For this reason, meeting the need for quality, cheap and abundant roughage regularly comes in the lead of the most important problems which require solving in the development of livestock raising in Turkey. In this study, the roughage production, the livestock and the roughage sufficiency level of Turkey were evaluated. 


\section{METHODS USED IN CALCULATIONS}

\section{Calculation of Roughage Production}

In this study, firstly the amount of dry roughage obtained from various sources was estimated, and then the values of the cattle, water buffalo, sheep and goat species were calculated in terms of animal unit (AU). A great part of the data used for estimation and calculation was obtained from the Turkish Statistical Institute (TÜIK) databases and the information which could not be derived from these databases was estimated by the author or compiled from different resources.

Production from meadows and pastures: The areas of rangelands and the hay yields of pastures according to the geographical regions were taken from the records of the General Directorate of Plant Production (BÜGEM) (Anonymous, 2020b). The hay yields of meadows according to the geographical regions were taken from the study conducted by Altın et al., (2011a). The hay productions of the regions were calculated by multiplying these values by the meadow and pasture areas.

Production from shrublands: The distribution of the shrublands according to the geographical regions and the grazable forage amounts were taken from the study conducted by Gökkuş (2019).

Straw production: In order to evaluate the grain and straw yields of cereals together, the criterion called "harvest index" is used. The harvest index is the ratio of the grain weight obtained from the unit area to the aerial biomass i.e. sum of straw and grain weights (Genç, 1978). In this study, the straw yield of any cereal per decare was calculated via the equation of (SY);

$S Y=G Y^{*}(100-H I)^{*} C T S H I^{-1}$

In the equation, GY: Grain yield $\left(\mathrm{kg} \mathrm{da}^{-1}\right)$, HI: Harvest index (\%), CTS: Coefficient of turning into straw, in other words, the amount of usable straw obtained from the total stems. The grain yields of the mentioned plants were taken from the TÜIKK databases, the values of the other elements included in the equation were estimated by the author (Table 1).

Table 1. Harvest and feedstuff/total vegetative biomass index used to estimation straw yield of cereals

\begin{tabular}{lccccc}
\hline Specifications & Wheat & Barley & Rye & Oats & Triticale \\
\hline Harvest index (HI) & 0.30 & 0.35 & 0.25 & 0.30 & 0.30 \\
Feedstuff/total vegetative biomass & 0.70 & 0.50 & 0.70 & 0.75 & 0.70 \\
\hline
\end{tabular}

Production from stubbles: Stubble is the common name given to residues such as root, stem, leaf, plant parts, etc. which remain on the soil surface in fields following the harvesting practices. In this study, the amount of dry matter remained as stubble was calculated via writing the value of 1-CTS, which is the ratio of the stubble remaining in the field (SRF), in place of the CTS multiplier included in the equation of straw yield per decare. It was assumed that $30 \%$ of the residue remaining in the field as stubble was grazed by animals (Deniz et al., 2010).

Production from forage crops: The information related to the sowing areas and yields of forage crops was obtained from the TÜİK databases (TÜİK, 2020a). In the calculation of the green forage in terms of hay, the maize (for silage and forage) was multiplied by the coefficient of 0.33 and the remaining plants were multiplied by the coefficient of 0.25 (Tan, 2017).

\section{Cattle, Water Buffalo, Sheep and Goat Stocks}

While calculating the roughage need, the value of each species was calculated in terms of AU by accepting a live weight of $500 \mathrm{~kg}$ as one AU. A great part of the coefficients used in the transformation of the numbers of animals into AUs were taken from the Rangeland Guideline published in the Official Gazette dated 31st July 1998 with numbered 23419 (Anonymous, 2020a). However, the described 
subgroups for each species and their provided numbers in the TÜIKK databases are more detailed compared to this guideline. Despite the consideration that it is necessary to determine new transformation values for each group included in the TÜIKK databases, in this study, current evaluation criteria were applied.

\section{Estimation of the Sufficiency of Roughage Production}

It is necessary that the hay consumption foreseen per animal or AU should be $2.5 \%$ of live weight (Altın et al., 2011b). In this evaluation, needs are calculated by transforming ruminants into AUs. However, this method might lead to some mistakes. For instance, the dry matter consumption of 2 heads of cattle weighing $250 \mathrm{~kg}$ is more than that of one head of cattle weighing $500 \mathrm{~kg}$. This suggests that calculating the needs on the basis of age groups and yield levels would be more logical and realistic. On the other hand, the data related to the grazing duration in stubble, herbaceous and shrubby rangelands, the grazing ratios, the species grazing on these lands and the grazing capacities of rangelands is imperfect, too. For instance, the assumption that the hay yield of a rangeland is the same every year or it is benefited from the stubble at the same level every year is not correct. Moreover, since there will be losses in the processes of harvest, transportation, storage and feeding, the produced and the consumed amounts of roughage are not the same. However, there is not sufficient information about these losses.

Despite the above-mentioned deficiencies, the total production including straw and stubble was taken into account in the calculations and it was accepted that half of the hay estimated to be obtained from pastures was consumed (Gökkuş, 2019).

\section{ROUGHAGE PRODUCTION OF TURKEY}

Dry, natural or silage type of forages with a low content of nutrients compared to their volume is understood in roughage term (Kutlu and Çelik, 2018). It is possible to list these as the ones obtained from meadows and herbaceous and shrubby pastures, the ones derived from forage crops, cereal straws, the waste and vegetative parts of such plants as sugar beet, etc. and stubble. While pastures and stubbles are benefited mostly by grazing animals, straws, meadow herbage and forage crops are served to animals as important elements of daily rations. In this section, in addition to the ones obtained from meadows and pastures and the ones grown as forage crops, straws and stubbles, which are the secondary products of cereal production, were discussed.

Meadow and pasture areas and production: The meadow and pasture areas of Turkey were determined as 14.6 million ha in the 2001 General Agricultural Census, and as it is seen in Table 2, it has been assumed that this figure did not change between the years 2001-2019.

In previous evaluations made in relation to the change of meadow and pasture areas, it was generally reported that while rangelands decreased, cultivated areas increased and negative situations in animal production were linked to this change (Anonymous, 2015). However, it was not dwelled upon change of the cultivation area per capita or the rangeland area per small and large ruminants and change of yield obtained from unit area. When such an approach is accepted, the rangeland areas, which was 9.10 da in 1950 per small ruminant (sheep and goat), for instance, it has been calculated as 2.76 da in 1990, and 3.01 da in 2019. In the same years the cultivated areas per capita were $6.97 \mathrm{da}, 4.39$ da and 2.26 da respectively (Table 2 ).

According to the General Agricultural Census of 2001 (DİE, 2004), the pasture area is 13167400 ha and the meadow area is $1449300 \mathrm{ha}$. By benefiting from the province-specific data, the meadow and pasture areas of the geographical regions were calculated and the results were presented in Table 3. 
Natural meadows and pastures are concentrated in the Eastern and Central Anatolian Regions (68.80\% of the total areas).

Table 2. Rangeland area per animal head and cropland area per capita by years

\begin{tabular}{lccccccc}
\hline Years & \multicolumn{2}{c}{$\begin{array}{c}\text { Cereals and other crop } \\
\text { products }\end{array}$} & \multicolumn{2}{c}{$\begin{array}{c}\text { Meadows and } \\
\text { pastures }\end{array}$} & \multicolumn{2}{c}{$\begin{array}{c}\text { Rangeland per animal } \\
\text { head, da }\end{array}$} & $\begin{array}{c}\text { Cropland } \\
\text { per capita, } \\
\text { da }\end{array}$ \\
\cline { 2 - 6 } & Million ha & Rate $(\boldsymbol{\%})^{\mathbf{1}}$ & Million ha & Rate $(\boldsymbol{\%})^{\mathbf{1}}$ & Small ruminants & $\begin{array}{c}\text { Small and large } \\
\text { ruminants }\end{array}$ & \\
\hline 1950 & 14.5 & 18.6 & 37.8 & 48.6 & 9.10 & 7.18 & 6.97 \\
1970 & 24.3 & 31.2 & 21.5 & 27.6 & 3.84 & 3.08 & 6.88 \\
1990 & 24.2 & 31.1 & 14.2 & 18.3 & 2.76 & 2.24 & 4.39 \\
2010 & 20.8 & 26.7 & 14.6 & 18.8 & 4.97 & 3.58 & 2.84 \\
2019 & 18.8 & 24.2 & 14.6 & 18.8 & 3.01 & 2.20 & 2.26 \\
\hline
\end{tabular}

${ }^{1}$ Share of croplands (\%) in total area of Turkey (77.8 million ha); Source: Erdoğan (1996); TÜiK (2014); TÜiK (2020a)

Table 3. Total meadows and pastures areas (ha) according to geographical regions

\begin{tabular}{lcccccccc}
\hline & Mediterranean & $\begin{array}{c}\text { Eastern } \\
\text { Anatolia }\end{array}$ & Aegean & $\begin{array}{c}\text { Southeast } \\
\text { Anatolia }\end{array}$ & $\begin{array}{c}\text { Central } \\
\text { Anatolia }\end{array}$ & Black Sea & Marmara & Turkey \\
\hline Meadows & 44900 & 823200 & 52800 & 47900 & 181900 & 247500 & 51100 & 1449300 \\
Pastures & 614400 & 4662300 & 750100 & 964600 & 4388300 & 1269200 & 518500 & 13167400 \\
Total & 659300 & 5485400 & 802900 & 1012600 & 4570200 & 1516600 & 569600 & 14616700 \\
\hline
\end{tabular}

Source: Anonymous (2020b)

In accordance with the explanation done in the section of material and methods, the region-specific hay productions were given in Table 4 and as it is seen in table, the hay production from the meadows and pastures of Turkey is about 13164210 tonnes. An approximately of 32.07\% of this production is obtained from the meadows and $67.93 \%$ of it is derived from the pastures. Moreover, $86.86 \%$ of 3666 850 tonnes of hay obtained from the meadows and $83.20 \%$ of 7440005 tonnes of hay produced in pastures are obtained from Eastern Anatolia, Black Sea and Central Anatolia regions.

Table 4. Total hay production obtained from meadows and pastures according to geographical regions

\begin{tabular}{|c|c|c|c|c|c|c|c|c|c|}
\hline & & Mediterranean & $\begin{array}{c}\text { Eastern } \\
\text { Anatolia }\end{array}$ & Aegean & $\begin{array}{c}\text { Southeast } \\
\text { Anatolia }\end{array}$ & $\begin{array}{c}\text { Central } \\
\text { Anatolia }\end{array}$ & $\begin{array}{c}\text { Black } \\
\text { Sea }\end{array}$ & Marmara & Turkey \\
\hline \multirow{2}{*}{$\begin{array}{l}\text { Yield, } \\
\mathrm{kg} \mathrm{da}^{-1}\end{array}$} & Meadows & 275 & 300 & 300 & 250 & 250 & 300 & 300 & - \\
\hline & Pastures & 50 & 90 & 60 & 45 & 45 & 100 & 60 & - \\
\hline \multirow{3}{*}{$\begin{array}{l}\text { Production, } \\
\text { tonnes }\end{array}$} & Meadows & 123475 & 2469600 & 158400 & 119750 & 454750 & 742500 & 153300 & 4221775 \\
\hline & Pastures $^{1}$ & 307200 & 4196070 & 450060 & 434070 & 1974735 & 1269200 & 311100 & 8942435 \\
\hline & Total & 430675 & 6665670 & 608460 & 553820 & 2429485 & 2011700 & 464400 & 13164210 \\
\hline
\end{tabular}

${ }^{1}$ Usable forage is accepted as a half of the total biomass production of the pastures;Source: Altın et al., (2011a); Anonymous (2020b)

Shrublands and hay production: Shrublands, maquis and shrubby rangelands take place among the important sources of roughage for sheep and partially for goat raising. In arid and semi-arid climatic regions, shrubs constitute an important source of feed in the summer when the herbaceous species turn yellow and their nutritional value decreases, and in the winter periods when growth stops (Dökülgen and Temel, 2015). The area of the shrubby rangelands in Turkey is 11463000 ha and the total amount of grazable forage produced from these areas is 11267000 tonnes (Table 5). Yields of shrublands areas change according to regions depending on not only ecological conditions such as soil and climatic factors but also productive forces and their rates in vegetation. Shrublands are concentrated in the Aegean and Mediterranean Regions (46.68\% of the total areas). 
Table 5. Total shrublands areas and hay production according to geographical regions

\begin{tabular}{lcccccccc}
\hline & Mediterranean & $\begin{array}{c}\text { Eastern } \\
\text { Anatolia }\end{array}$ & Aegean & $\begin{array}{c}\text { Southeast } \\
\text { Anatolia }\end{array}$ & $\begin{array}{c}\text { Central } \\
\text { Anatolia }\end{array}$ & $\begin{array}{c}\text { Black } \\
\text { Sea }\end{array}$ & Marmara & Turkey \\
\hline Area, ha & 2049000 & 1173000 & 3210000 & 966000 & 1453000 & 1726000 & 886000 & 11463000 \\
Production, tonnes & 2049000 & 938400 & 3210000 & 772800 & 1162400 & 2071200 & 1063200 & 11267000 \\
\hline
\end{tabular}

Source: Gökkuş (2019)

Straw production: Although it is claimed that the overuse of the straw and stubble group of forages in animal feeding affects the digestibility of other high-value forage materials included in the ration negatively (Alçiçek, 2012; Ak and Akbay, 2018), some of the ruminant breeders in Turkey are left no choice but to feed their animals with straw and/or graze their herds in stubbles due to the shortfall of quality forage.

The cereal sown area, which was 12100000 ha in 2010 in Turkey, decreased to 11713000 ha in 2015 and 10772000 ha in 2019. In the mentioned period, while the cereals whose cultivated areas decreased most rapidly were wheat $(1.86 \%)$ and rye $(2.51 \%)$, the oat $(2.44 \%)$ and triticale $(10.15 \%)$ cultivated areas increased by annually. However, the annual average decrease in barley cultivated areas remained under $1 \%$ (Table 6 ).

The straw obtained from cereals is not evaluated only as forage. For instance, according to the Ministry of Agriculture and Forestry, the annual straw production is 25.0 million tonnes, $60 \%$ of which (15.0 million tonnes) is used in livestock farming (Anonymous, 2019). However, Alçiçek et al., (2010) reported that the amount of straw obtained from wheat, barley, oat and rye as 40.8 million tonnes in 2008 .

The straw production calculated as explained before by multiplying yield per decare by the cultivated area was presented in Table 6 . The amount of straw obtained from the commonly-cultivated cereals was estimated to be 43085000 tonnes in 2019. About $72.03 \%$ of the straw production was derived from wheat and $24.57 \%$ of it was obtained from barley. When it is estimated that $60 \%$ of the produced straw is fed to animals, it can be assumed that the straw production of Turkey to be used as animal forage is 25851000 tonnes in 2019.

Table 6. Sown areas and straw yield of commonly grown cereals by years

\begin{tabular}{lcccccc}
\hline Years & Wheat & Barley & Rye & Oats & Triticale & Total \\
\hline 2010 & 8103000 & 3040000 & 141000 & 88000 & 27000 & 12100000 \\
2015 & 7867000 & 2784000 & 112000 & 103000 & 37000 & 11713000 \\
2019 & 6846000 & 2869000 & 112000 & 110000 & 64000 & 10772000 \\
ACR* & -1.86 & -0.64 & -2.51 & 2.44 & 10.15 & $-1,28$ \\
\hline \multicolumn{7}{c}{ Sown area (ha) } \\
\hline 2010 & 32134000 & 10098000 & 768000 & 357000 & 152000 & 43509000 \\
2015 & 36913000 & 11143000 & 693000 & 438000 & 204000 & 49391000 \\
2019 & 31033000 & 10586000 & 651000 & 464000 & 351000 & 43085000 \\
\hline
\end{tabular}

*ACR: The annual change rate for the years 2010-2019; Source: TÜİK (2020a)

Table 7. Straw yield (tonnes) of cereals according to geographical regions (in 2019)

\begin{tabular}{lcccccccc}
\hline & & Eastern & Southeast & Central & & \\
Crops & Mediterranean & Anatolia & Aegean & Anatolia & Anatolia & Black Sea & Marmara & Turkey \\
\hline Wheat & 3241400 & 1780400 & 2593300 & 5260900 & 10553700 & 2930100 & 4673600 & 31033300 \\
Barley & 608700 & 867900 & 1168800 & 1222600 & 5493000 & 736800 & 487800 & 10585700 \\
Others & 66400 & 111100 & 192200 & 800 & 683600 & 201800 & 210100 & 1466100 \\
Total & 3916500 & 2759400 & 3954300 & 6484300 & 16730300 & 3868700 & 5371500 & 43085000 \\
\hline
\end{tabular}

Source: TÜİK (2020a) 
The amounts of straw produced from cereals differ according to the geographical regions. More than half of the total straw production (53.88\%) is obtained from the Central Anatolia and the Southeast Anatolia regions (Table 7).

Amount of forage production from stubbles: Although there are various estimations about the amount of straw obtained from cereal cultivated areas, there is not clear information about to which extent animals benefit from stubbles. However, Deniz et al., (2010) reported in a study conducted in Şanliurfa Province that when the wheat has an average length of $100 \mathrm{~cm}$ and the length of left stubble is $15 \mathrm{~cm}$, $22.4 \%$ of the whole stubble weight and when the length of left stubble is $20 \mathrm{~cm}, 34 \%$ of it was left in the field. In this study, as explained before, it was assumed that only $30 \%$ of the estimated stubble was grazed by animals. When these assumptions are accepted, the amount of stem parts left as stubble in fields in 2019 was calculated as 17412667 tonnes and it was estimated that 5223800 tonnes of this were consumed by grazing animals. The great majority of the mentioned amount is wheat and barley stubble and the Central Anatolia takes the first place in terms of production (Table 8).

Table 8. Stubble yield (tonne) for grazing according to geographical regions (in 2019)

\begin{tabular}{cccccccc}
\hline Mediterranean & $\begin{array}{c}\text { Eastern } \\
\text { Anatolia }\end{array}$ & Aegean & $\begin{array}{c}\text { Southeast } \\
\text { Anatolia }\end{array}$ & $\begin{array}{c}\text { Central } \\
\text { Anatolia }\end{array}$ & $\begin{array}{c}\text { Black } \\
\text { Sea }\end{array}$ & Marmara & Turkey \\
\hline 485500 & 328200 & 473700 & 798800 & 1987800 & 475800 & 674000 & 5223800 \\
\hline Source: TÜंK (2020a) & & & & & & &
\end{tabular}

Source: TÜIK (2020a)

Cultivated area and production of forage crops: Among the cultivated areas, while the share of forage crops was $8.95 \%$ in 2010 , it increased to $13.63 \%$ in 2019 . In other words, while the annual increase rate of the area allocated for forage crops in this period became $4.10 \%$, the fallow areas decreased by $2.49 \%$ and the sown areas decreased by $0.66 \%$. In this period, the maize (for silage) and alfalfa cultivated areas increased annually by $6.26 \%$ and $1.34 \%$, respectively and the common vetch sowing area decreased by $1.01 \%$ (Table 9).

Table 9. Sowing areas (ha) of forage crops by years

\begin{tabular}{lccccccccc}
\hline \multirow{3}{*}{ Years } & \multicolumn{3}{c}{$\begin{array}{c}\text { Cereals and other crop } \\
\text { products }\end{array}$} & \multicolumn{7}{c}{ Forage crops } \\
\cline { 2 - 11 } & Sown area Fallow land & Alfalfa & Maize & Vetch & Sainfoin & Grasses** & Others*** & Total \\
\hline 2010 & 16333000 & 4249000 & 569000 & 294000 & 429000 & 157000 & 0 & 12000 & 1461000 \\
2015 & 15723000 & 4114000 & 662000 & 423000 & 437000 & 191000 & 111000 & 39000 & 1863000 \\
2019 & 15387000 & 3387000 & 641000 & 507000 & 391000 & 175000 & 345000 & 38000 & 2097000 \\
ACR*, \% & -0.66 & -2.49 & 1.34 & 6.26 & -1.01 & 1.23 & 33.08 & 13.66 & 4.10 \\
\hline Share in the sown & 2010 year & 3.48 & 1.80 & 2.63 & 0.96 & 0.00 & 0.07 & 8.95 \\
area, \% & 2019 year & 4.17 & 3.30 & 2.54 & 1.14 & 2.24 & 0.25 & 13.63 \\
\hline
\end{tabular}

*ACR: The annual change rate for the years 2010-2019; **: Oat, barley, triticale, wheat, annual ryegrass (The annual change rate for the years 2015-2019); ***: Forage pea, grass pea, forage rape, sorghum, bitter vetch; Source: TÜİ (2020a)

The forage crops taking the first place in Turkey in terms of both of the area as well as production are maize, alfalfa, vetch and sainfoin. The green forage production of these four forage crops is $89.50 \%$ of 55519000 tonnes, which is the total production of 2019. In the total production, the share of maize (for silage and forage) was $46.20 \%$ and that of green alfalfa was $32.33 \%$. While the total production of forage crops was 30074000 tonnes in 2010, it increased to 55519000 tonnes in 2019 by increasing annually by $7.05 \%$ (Table 10). These values can be interpreted in the way that the intensive ruminant breeding in Turkey has become widespread and, hence, the roughage production has been made mainly from maize and alfalfa. 
Table 10. Total green forage yields (tonnes) obtained from forage crops by years

\begin{tabular}{cccccccc}
\hline Years & Alfalfa & Maize & Vetch & Sainfoin & Grasses $* *$ & Others*** & Total \\
\hline 2010 & 11676000 & 12654000 & 4019000 & 1509000 & 0 & 216000 & 30074000 \\
2015 & 13950000 & 19920000 & 4281000 & 1656000 & 1475000 & 754000 & 42036000 \\
2019 & 17949000 & 25652000 & 4304000 & 1782000 & 4986000 & 846000 & 55519000 \\
ACR $^{*} \%$ & 4.89 & 8.17 & 0.76 & 1.86 & 35.59 & 16.38 & 7.05
\end{tabular}

*ACR: The annual change rate for the years 2010-2019; **: Oat, barley, triticale, wheat, annual ryegrass (The annual change rate for the years 2015-2019); ***: Forage pea, grass pea, forage rape, sorghum, bitter vetch; Source: TÜIK (2020a)

The productions of forage crops differ significantly according to the geographical regions. In the production of alfalfa and sainfoin, the Eastern Anatolia Region takes the first place while in the production of maize and other forage crops, the Aegean and Marmara Regions take the first places (TÜİK, 2020a).

Total roughage production: The roughage sources examined in detail above compose nearly all of the roughage which Turkey can provide and the 2019 geographic region-specific values of these were given in Table 11. As it is seen in the table, of 71438010 tonnes of dry roughage estimated to have been produced in $2019,5.91 \%$ is obtained from meadows, $12.52 \%$ from pastures, $15.77 \%$ from shrublands, $43.50 \%$ from sum of the straws and stubbles, and $22.30 \%$ from forage crops production. In the forage crops production, the first two ranks are occupied by the Aegean and the Central Anatolia regions; in the straws and stubbles production, the Central Anatolia and the Southeast Anatolia regions take the first and the second places; in the production made from pastures, the Eastern and the Central Anatolia occupy the first and the second places.

Table 11. Total roughage production (tonnes) according to geographical regions (in 2019)

\begin{tabular}{lccccccc}
\hline Regions & Forage Crops & Meadows & Pastures & Shrublands & Straw & Stubble & Total \\
\hline Mediterranean & 940000 & 123475 & 307200 & 2049000 & 2349900 & 485500 & 6255075 \\
Eastern Anatolia & 2525000 & 2469600 & 4196070 & 938400 & 1655640 & 328200 & 12112910 \\
Aegean & 3790000 & 158400 & 450060 & 3210000 & 2372580 & 473700 & 10454740 \\
Southeast Anatolia & 655000 & 119750 & 434070 & 772800 & 3890580 & 798800 & 6671000 \\
Central Anatolia & 3304000 & 454750 & 1974735 & 1162400 & 10038180 & 1987800 & 18921865 \\
Black Sea & 1688000 & 742500 & 1269200 & 2071200 & 2321220 & 475800 & 8567920 \\
Marmara & 3030000 & 153300 & 311100 & 1063200 & 3222900 & 674000 & 8454500 \\
Turkey & 15932000 & 4221775 & 8942435 & 11267000 & 25851000 & 5223800 & 71438010 \\
Share, \% & 22.30 & 5.91 & 12.52 & 15.77 & 36.19 & 7.31 & 100.00 \\
\hline Source: Altın et al.,(2011a); Gökkus (2019); TÜİ (2020a); Anonymous (2020b) & & & &
\end{tabular}

\section{Cattle, Water Buffalo, Sheep and Goat Stock in Turkey}

The number of animals: The small and large ruminants of Turkey between the years 2005-2019 according to the TÜIKK and their annual average change rates were presented in Table 12. It is seen that the livestock in the species included in the table has been increased rapidly starting from 2009. Such that, the average rate of increase in the period of 10 years between the years 2009-2019 was 5.13\% in cattle, $7.75 \%$ in water buffalo, 5.54\% in sheep, $8.21 \%$ in hair goat, and 5.07\% in Angora goat.

The change in the number of animals between the years 2009-2019 did not remain limited to numerical increase but the share of culture cattle increased from $31.86 \%$ to $40.58 \%$ (TÜIK, 2020b). Especially, it is expected that the increase in the shares of culture and cross-bred in the species of cattle has made the need for quality roughage and concentrate feed more evident. In fact, that the productions of alfalfa and maize (for silage and forage) have increased rapidly especially in recent years can be evaluated as a result of this change. 
Table 12. Cattle, buffalo, sheep and goat numbers (heads) by years

\begin{tabular}{lccccc}
\hline Years & Cattle & Buffaloes & Sheep & Goats - Hair & Goats - Angora \\
\hline 2009 & 10723958 & 87207 & 21749508 & 4981299 & 146986 \\
2010 & 11369800 & 84726 & 23089691 & 6140627 & 152606 \\
2015 & 13994071 & 133766 & 31507934 & 10210338 & 205828 \\
2019 & 17688139 & 184192 & 37276050 & 10964374 & 241055 \\
ACR $* \%$ & 5.13 & 7.75 & 5.54 & 8.21 & 5.07 \\
\hline
\end{tabular}

*ACR: The annual change rate for the years 2009-2019; Source: TÜİK (2020b)

Livestock in terms of animal units (AU): By accepting the live weight as $500 \mathrm{~kg}$ for an AU, the values of each species were calculated in terms of $A U$ and the results were presented in Table 13. As it is seen in the table, total AU were calculated as 17066900 in 2019. Between the years 2009-2019, the AU increased 1.8 times but there was non-significant change in the shares of the species, particularly those of cattle and sheep.

Table 13. Animal unit values of cattle, sheep, goat and buffalo and their shares in livestock by years

\begin{tabular}{lccccccccc}
\hline \multirow{2}{*}{ Years } & \multicolumn{2}{c}{ Cattle } & \multicolumn{2}{c}{ Buffaloes } & \multicolumn{2}{c}{ Sheep } & \multicolumn{2}{c}{ Goats } & Total \\
\cline { 2 - 8 } & AU & \% & AU & \% & AU & \% & AU & \% & AU \\
\hline 2009 & 7021600 & 74.10 & 69200 & 0.73 & 2006200 & 21.17 & 378900 & 4.00 & 9475900 \\
2010 & 7489200 & 73.52 & 66700 & 0.65 & 2156100 & 21.17 & 474300 & 4.66 & 10186300 \\
2015 & 9784300 & 71.62 & 104500 & 0.77 & 2975400 & 21.78 & 798000 & 5.84 & 13662300 \\
2019 & 12434200 & 72.86 & 145200 & 0.85 & 3613800 & 21.17 & 873700 & 5.12 & 17066900 \\
\hline
\end{tabular}

Source: Anonymous (2020a); TÜİK (2020b)

\section{Sufficiency of Total Roughage Production for Livestock}

The roughage production per AU, which was a total of $6318.53 \mathrm{~kg}$ in 2010 , declined to 4185.76 $\mathrm{kg}$ with a decrease of $33.75 \%$ in 2019 (Table 14). During this period, the AU increased by a total of $67.55 \%$ (Table 13), while the total increase observed in roughage production remained at the level of $10.99 \%$. The increase in the forage crops production, which is the only source of this increase, reached $86.76 \%$. However, due to the increase in the number of animals, the reflection of this increase into daily consumption per AU took place in the form of increasing the dry matter production obtained from forage crops from $837.48 \mathrm{~kg}$ to $933.50 \mathrm{~kg}$ (Table 14). If the total roughage per AU is divided by 365 , it is seen that the amount of daily consumable roughage decreased from $17.31 \mathrm{~kg}$ to $11.47 \mathrm{~kg}$. However, nearly half of this value came from straws and stubbles production.

Table 14. Total roughage production, and roughage per animal units by years

\begin{tabular}{ccccccccc}
\hline Years & Forage Crops & Meadows* & \multicolumn{2}{c}{ Pastures* } & Shrublands* & Straw & Stubble & Total \\
\hline \multicolumn{7}{c}{ Total roughage production (tonnes) } \\
2010 & 8530820 & 4221775 & 8942435 & 11267000 & 26105400 & 5295000 & 64362430 \\
2015 & 12102600 & 4221775 & 8942435 & 11267000 & 29634600 & 6019000 & 72187410 \\
2019 & 15931910 & 4221775 & 8942435 & 11267000 & 25851000 & 5223800 & 71437920 \\
\hline \multicolumn{7}{c}{ Roughage per animal units $\left(\mathrm{kg} \mathrm{year}^{-1}\right)$} \\
\hline 2010 & 837.48 & 414.46 & 877.89 & 1106.09 & 2562.80 & 519.82 & 6318.53 \\
2015 & 885.84 & 309.01 & 654.53 & 824.68 & 2169.08 & 440.56 & 5283.69 \\
2019 & 933.50 & 247.37 & 523.96 & 660.17 & 1514.69 & 306.08 & 4185.76 \\
\hline
\end{tabular}

*It is assumed that the area has not changed after 2010 with the yield per decare

Considering the daily dry roughage requirement as $12.5 \mathrm{~kg}$ (approximately 2.5 percent of total 500 $\mathrm{kg}$ live weight), deficiency of daily feed amount was estimated as $1.032 \mathrm{~kg}$ AU-1 in 2019. In this case, the total roughage deficit can be calculated as 6429720 tonnes in 2019. If shrublands, straw and stubble production is neglected or removed from the calculation, then total deficiency reaches at 48771521 tonnes year-1. In previous studies, Acar et al., (2020) reported annual quality roughage production as 31.0 million tonnes, roughage need 86.9 million tonnes, roughage deficit as 55.9 million tonnes. Özkan 
(2020) determined the annual quality roughage production as 29.1 million tonnes, the roughage need as 85.4 million tonnes, and the total roughage deficit as 56.3 million tonnes. Our findings are in fully agreement with those previous studies.

However, considering the sugar beet, vegetable and fruit residues and the weeds on the fields and roadsides, it may not be mentioned about the roughage deficit. The main problem is the lack of quality roughage. Only $37.37 \%$ of the total roughage requirement, which is 77867731 tonnes, is provided by quality roughages obtained from forage crops, meadows and pastures. Since the remaining part (approximately $62.63 \%$ consists of feeds having low nutritional value, breeders have to give more concentrated feed especially to the culture cattle. This situation increases the cost of animal products. The total roughage deficit is $40.36 \%$ of the total forage crops production. Hence, in order to meet the need of our country, it is necessary to increase the forage crops production to about 22500000 tonnes. Apart from the widely produced legume and grass forage crops, alternative forage crops that are cultivated or found in natural vegetation, resistant to adverse climatic conditions, diseases and pests should also be evaluated (Tan and Temel, 2012).

\section{CONCLUSION}

Overall data obtained in this study suggest that it is necessary to focus on the products that will cover the quality roughage gap in animal feeding. Increasing the amount of hay produced from forage crops, meadows and pastures will serve this aim. By considering the climatic and topographical features, crop cultivation patterns and fallow areas of Turkey, it can be suggested that areas to cultivate forage crops can be increased by acreage. In addition, the abandoned agricultural land, which has been 3250 000 ha for the last 20 years, should be reserved to production, winter fodder crops should be rotated in irrigated agricultural land and forage plants should be used to decrease fallow lands. Besides, a series of precautions should be taken to conserve our meadows and pastures. The appropriate management and improvement of rangelands should be the primary target. The regulations facilitating the change of allocation aim included in the 14th article of the Rangeland Law should be abolished and the allocation aim changes should be made more difficult. In Turkey, many shrublands were taken within forest borders and grazing animals in these areas has been prohibited. Grazing should be allowed both in these areas, which will never turn into forests and in higher forest areas, where grazing doesn't harm to ecosystem. Region-specific and production system-specific grazing regulations should be prepared and primarily breeders should be made to adopt these regulations.

\section{Conflict of Interest}

The article authors declare that there is no conflict of interest between them.

\section{Author's Contributions}

The authors declare that they have contributed equally to the article.

\section{REFERENCES}

Acar Z, 2017. Kaba Yem Üretimi ve Sorunları. Türkiye'nin Hayvansal Üretimi (Mevcut Durum ve Gelecek) Sempozyumu, 10-11 Ocak 2017, Ankara, pp: 159-169.

Acar Z, Tan M, Ayan İ, Aşçı ÖÖ, Mut H, Başaran U, Gülümser E, Can M, Kaymak G, 2020. Türkiye'de Yem Bitkileri Tarımının Durumu ve Geliştirme Olanakları. Türkiye Ziraat Mühendisliği IX. Teknik Kongresi, 13-12 Ocak 2020, Ankara, pp: 529-554.

Ak İ, Akbay KC, 2018. Buğday Samanının Yem Değeri ve Hayvan Beslemede Kullanımı. TÜRKTOB Dergisi, 25: 20-22. 
Alçiçek A, 2012. Türkiye'de Kaba Yem Üretimi ve Yeterlilik Durumu. Tarım ve Mühendislik Dergisi, 101-102: 36-39.

Alçiçek A, Kılıç A, Ayhan V, Özdoğan M, 2010. Türkiye'de Kaba Yem Üretimi ve Sorunları. Türkiye Ziraat Mühendisliği VII. Teknik Kongresi. Cilt: 2, 11-15 Ocak 2010, Ankara, pp: 1071-1080.

Altın M, Gökkuş A, Koç A, 2011a. Çayır ve Mera Yönetimi Genel İlkeler I. Cilt. Tarım ve Köyişleri Bakanlığı, TÜGEM, Ankara, 376 p.

Altın M, Gökkuş A, Koç A, 2011b. Çayır ve Mera Yönetimi Temel İlkeler II. Cilt. Tarım ve Köyişleri Bakanlığı, TÜGEM, Ankara, 314 p.

Anonymous, 2015. Gıda Tarım ve Hayvancılık Bakanlığı GTHB, Kırmızı Et Stratejisi. Ankara, 76 p.

Anonymous, 2019. Asılsız İddialar ve Gerçekler, https://www.tarimorman.gov.tr/Belgeler/\%C4\% B0ddialar\%20ve\%20Ger\%C3\%A7ekler.pdf, (Date of access: 11 July 2020).

Anonymous, 2020a. Mera Yönetmeliği, https://www.mevzuat.gov.tr/Metin.Aspx?MevzuatKod= 7.5.5057\&MevzuatIliski=0\&sourceXmlSearch, (Date of access: 11 July 2020).

Anonymous, 2020b. Çayır Mera ve Yem Bitkileri, https://www.tarimorman.gov.tr/Konular/BitkiselUretim/Cayir-Mera-ve-Yem-Bitkileri, (Date of access: 11 July 2020).

Deniz İ, Tutuş A, Ateş S, Okan OT, 2010. Buğday Sapının Hasat İndeksi ve Soda-Oksijen-AQ Pişirmesi. III. Ulusal Karadeniz Ormanc1lık Kongresi, 20-22 May1s 2010, 5: 2052-2060.

DİE, 2004. 2001 Genel Tarım Sayımı, Köy Genel Bilgileri. Yayın No: 2898, Ankara.

Dökülgen H, Temel S. 2015. Yaprağını döken karaçalı (Palirus spina-christi Mill.) türünde yaprak ve yaprak + sürgünlerinin mevsimsel besin içeriği değişimi. Iğdır Üniversitesi Fen Bilimleri Enstitüsü Dergisi, 5(3): 57-65.

Erdoğan M, 1996. Türkiye Tarımında Doğal Kaynaklar ve Çevre Sorunu. Doktora Tezi, Marmara Üniversitesi Sosyal Bilimler Enstitüsü, İstanbul, 186 p.

Genç İ, 1978. Tahıllarda Tane Veriminin Fizyolojik ve Morfolojik Esasları. Çukurova Üniversitesi Ziraat Fakültesi Yıllı̆̆ı, 81: 1-26.

Gökkuş A, 2019. Organik Hayvancılığın Kaba Yem Kaynakları: Çayır-Mera ve Çalılı Alanlar. VI. Organik Tarım Sempozyumu Bildirileri, 15-17 Mayıs 2019, İzmir.

Kutlu HR, Çelik L, 2018. Yemler Bilgisi ve Yem Teknolojisi. Çukurova Üniversitesi Ziraat Fakültesi Yayın No: 266, Adana, 378 p.

Özkan U, 2020. Türkiye Yem Bitkileri Tarımına Karşılaştırmalı Genel Bakış ve Değerlendirme. Türk Ziraat Mühendisliği Araştırmaları Dergisi, 11: 29-43.

Tan M, 2017. Muş Tarımında Yem Bitkilerinin Önemi ve Alternatif Yem Bitkileri. Muş Ovası Tarım ve Hayvancılık Çalıştayı, 15-16 Mayıs, Muş, pp: 97-110.

Tan M, Temel S. 2012. Alternatif Yem Bitkileri, Atatürk Üniversitesi Ziraat Fakültesi Ders Yayınları No: 246, Erzurum, 233 p.

Temel S, Şahin K, 2011. Iğdır İlinde Yem Bitkilerinin Mevcut Durumu, Sorunları ve Çözüm Önerileri. Yüzüncü Y1l Üniversitesi Tarım Bilimleri Dergisi, 21(1): 64-72.

TÜİK, 2014. İstatistik Göstergeler 1923-2013. Yayın No: 4361, Ankara.

TÜIK, 2020a. Bitkisel Üretim İstatistikleri Veri Taban1, https://biruni.tuik.gov.tr/ medas/?kn=92\&locale=tr, (Date of access: 11 July 2020).

TÜIK, 2020b. Hayvansal Üretim İstatistikleri Veri Taban1, https://biruni.tuik.gov.tr/ medas/?kn=101\&locale=tr, (Date of access: 11 July 2020). 